\title{
手指の内軟骨腫に対する内視鏡下手術の小経験
}

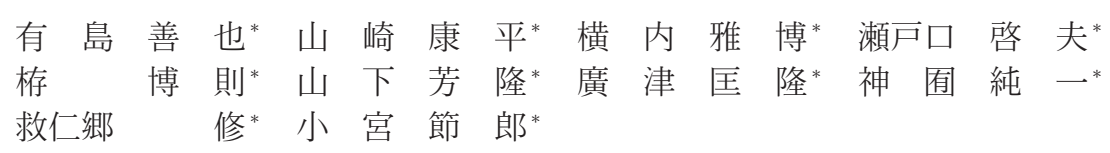

\section{Short-Term Clinical Results of Endoscopic Curettage for Enchondroma in Hand}

Yoshiya Arishima*, Kohei Yamasaki*, Masahiro Yokouchi*, Takao Setoguchi*, Hironori Kakoi*, Yoshitaka Yamashita*, Masataka Hirotsu*, Junichi Kamizono*, Osamu Kunigo*, and Setsuro Komiya*

手指に生じた内軟骨腫 4 例に対して内視鏡補助下に腫瘍择爬術，骨ペースト移植術を施行した。術後平 均 10 か月の短期成績に抢いて, 腫瘍再発はなく, 関節可動域は術後 1 か月で術前レベルに回復した。 1 例で骨ペーストの骨外漏出を認めたものの臨床的に問題はなかった。内視鏡下腫瘍搔爬術は小皮切，早期 リハビリテーション，拡大画像による確実な掻爬など多くの利点を有する優れた方法である.

With the current spread of minimum invasive surgery, successful results have been reported for endoscopic surgery of the hand such as triangular fibrocartilage complex, carpal tunnel syndrome, etc. This study discusses four cases of enchondroma in the hand, which was treated with endoscopic curettage and $\alpha$-TCP grafting. Regarding the short term results (10 months after surgery on average), no recurrence of tumor was observed and full range of motion of the digit was gained within one month after surgery in all patients. In one patient, grafted $\alpha$-TCP leaked out extraskeletally, but it was absorbed within three months and no clinical defecits such as pain and loss of range of motion were seen. This procedure has several advantages such as minimum skin incision, early exercise of range of rehabilitation and expanded visual field with endoscope. In our cases, good results were obtained with this procedure.

Key words : enchondroma (内軟骨腫), endoscopic surgery (内視鏡手術), hand surgery (手の外科)

\section{は じめに}

近年手の外科の領域においても, 手根管症候群や狭 窄性腱鞘炎などに対して積極的に内視鏡手術が導入さ れつつある. 当院では 2005 年より手指の内軟骨腫に 対して内視鏡視下に腫瘍掻爬術を行っており, 今回そ の手術手技と短期治療成績について報告する.

\section{対象}

計 4 手（男性 1 手，女性 3 手), 手術時年齢は平均 47.3 歳（13～67 歳), 罹患指は母指 1 手, 示指 2 手, 環指 1 手であり, 術後経過観察期間は平均 10 か月（7
か月〜1年 2 か月）である.

\section{手 術手技}

まず X 線透視下に腫瘍の対角線方向に 2 か所の骨 孔を開空し鋭匙にて腫瘍の部分掻爬を行い working space の確保を行う. 次いで内視鏡を挿入し鋭匙やシェー バーを入北替え, 生理食塩水で骨䯣腔を適宜 washout して内壁の正常骨が露出するまで掻爬する，最後 に骨孔より骨ペースト（ $\alpha$-TCP）を注入し皮膚縫合 して手術を終了する。術後外固定は行わず，翌日より 手指の自動運動を開始させる。内視鏡は $2.3 \mathrm{~mm}$ 径の Stryker 社製 TMJ ミニスコープを用いている.

\footnotetext{
* 鹿児島大学大学院運動機能修復学講座整形外科学 Department of Orthopaedic Surgery, Kagoshima Graduate School of Medical and Dental Sciences, Kagoshima, Japan
} 

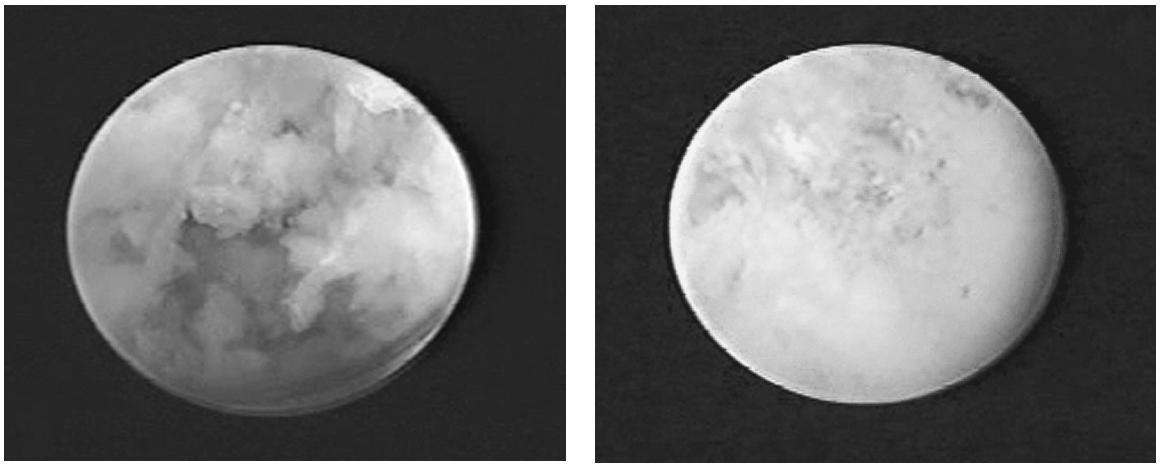

図 1 症例 1 （59 歳女性，母指末節骨例）の内視鏡所見 ; X 線透 視下に鋭匙である程度の掻爬を行った後に内視鏡を挿入する と (左図), 皮質骨内壁に腫瘍が付着しているのが良く観察 される. 鋭匙, シェーバーによる掻爬や生理食塩水による洗 浄操作を繰り返して行くうちに次第に正常な皮質骨が観察さ れるようになる (右図).
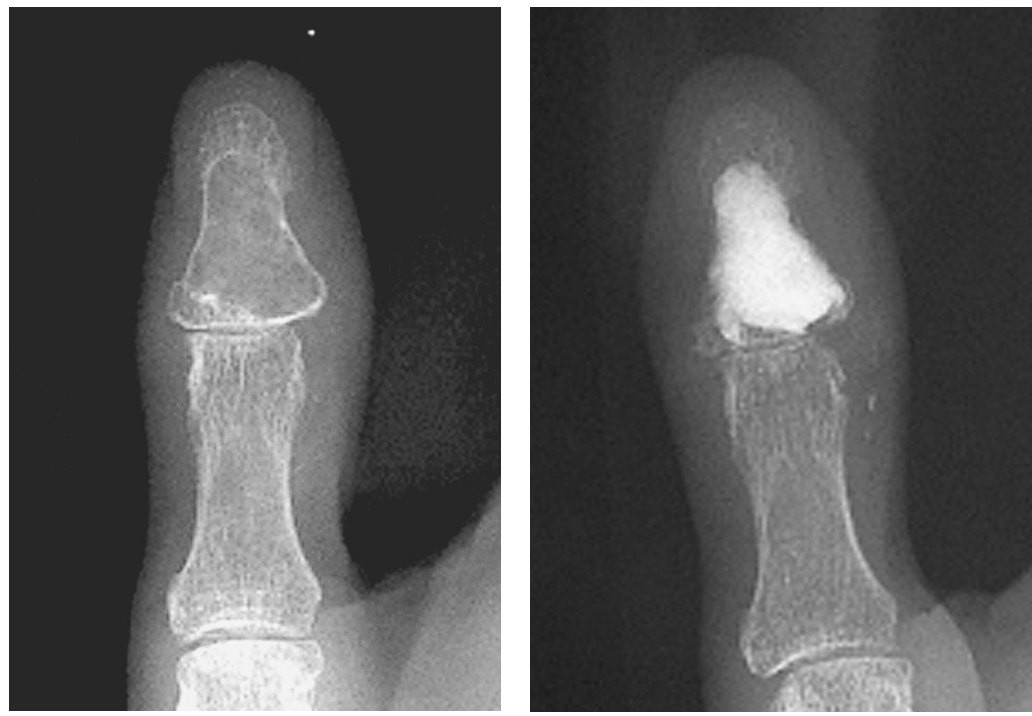

図 2 症例 1 の画像所見 ; 術前単純 X 線像（左図）では辺縁硬化 像を伴う骨透亮像を呈しており典型的な内軟骨腫之診断され た。本法施行後 1 年の単純 X 線像（右図）では腫瘍再発は 認めない，骨ペーストの吸収置換はなされていない,

\section{治 療 成 績}

今回の症例では短期ではあるが腫瘍再発はなく，関 節可動域む全例 1 か月以内に術前レベルに回復した。 感染症や神経損傷など重篤な合併症はなかった。1例 で骨ペーストが皮下漏出したが，術後 3 か月でほぼ吸
収され可動域制限や疼痛む生じなかった。

\section{症 例 供 覧}

《症例 $1 》 59$ 歳女性，母指末節骨例

辺縁硬化像を伴う骨透亮像が認められ，発生部位か らむ内軟骨腫が強く疑われた。前述の手技にて内視鏡 

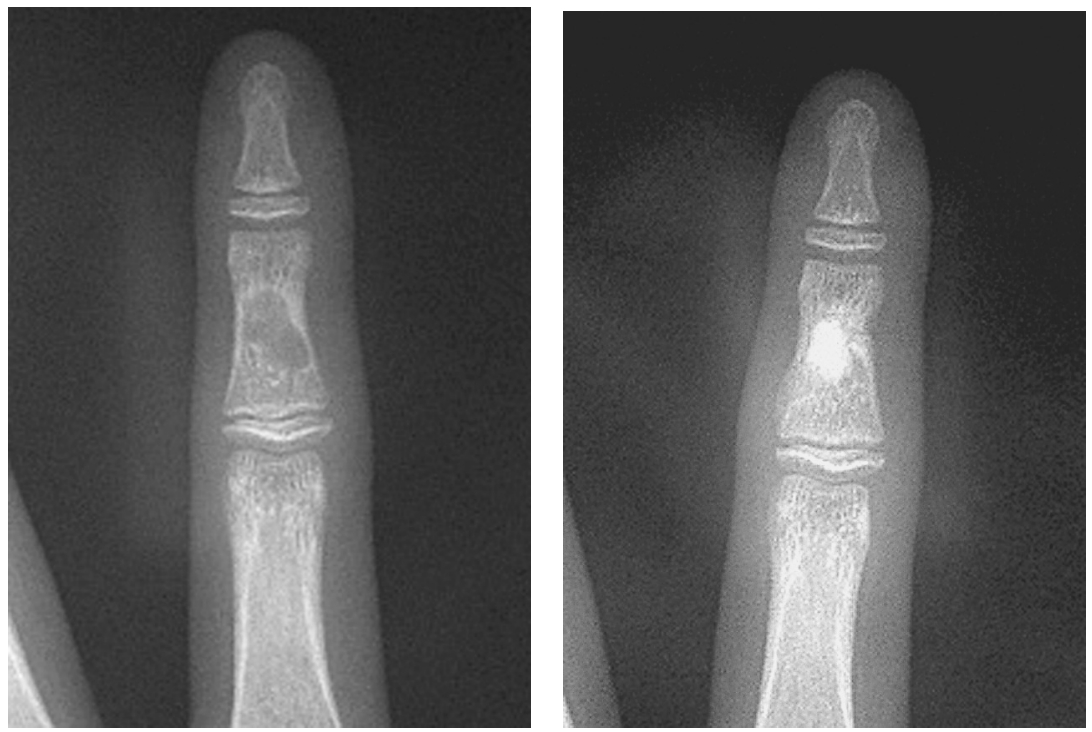

図 3 症例 2 の画像所見; 本例は病的骨折の骨癒合を待って手術を 行った (左図). 手術後 1 か月で術前レベルの可動域に回復 した。本法施行後 7 か月の単純X線像 (右図) で腫瘍再発は 認めない.

視下に腫瘍掻爬術を施行した（図 1 )。術中迅速検査 を行い内軟骨腫であることが確認されたため可及的に 择爬後，骨ペーストを充填した。術後 1 か月で関節可 動域は full range となり, 術後 1 年時の単純 X 線で は腫瘍の再発はないが骨ペーストの置換もなされてい ない(図 2 ).

《症例 2 》13 歳男児，示指中節骨例

病的骨折にて発症したため，骨癒合と関節可動域の 回復を待ってから手術を施行した（図 3 ）。閉創後の 肉眼写真（図 4) で示されるように小皮切での手術が 可能である.

考察

近年，最小侵襲手術の観点から良性骨腫瘍に対する 内視鏡下手術の報告が散見されるようになった。手指 内軟骨腫においては，小林ら ${ }^{1)}$ は 29 例の 6 か月以上 の経過観察において腫瘍再発や術後感染はなく骨移植 を施行しなくとも術後平均 2.4 か月からリモデリング が認められ有用な術式であるとし，湯川ら ${ }^{4)}$ は骨ぺー スト注入を併用した 7 例において術後平均 27.1 か月 で再発なく，骨ペーストが皮下に漏れた場合も3 か月

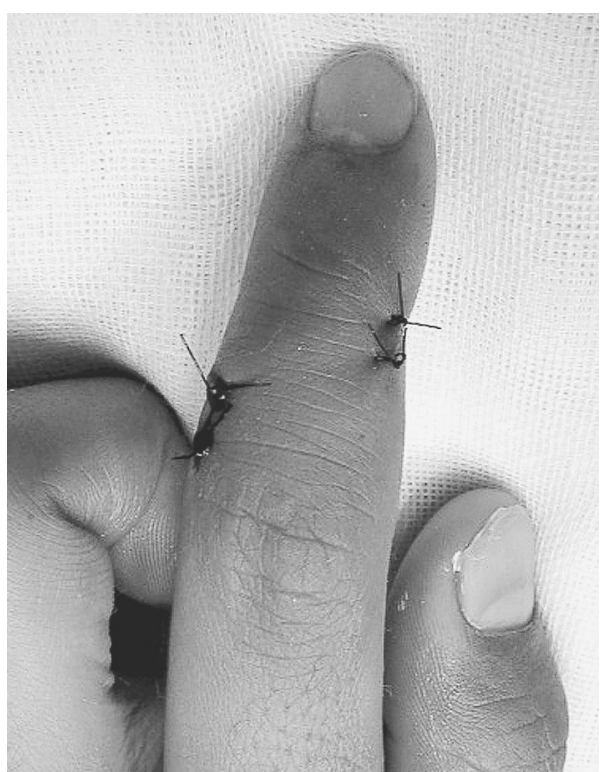

図 4 症例 2 の閉創後の外観；小皮切 であり整容的に優れている. 
で吸収され機能障害はなかったと述べている。内軟骨 腫以外の内視鏡視下腫瘍掻爬術の治療成績については, 関谷ら ${ }^{3)}$ は内軟骨腫の他に動脈瘤様骨囊腫, 単発性骨 囊腫，骨内ガングリオンに対しても鏡視下掻爬術を施 行し, Ollier 病の 1 例が再発した以外は全例再発なく 有用な術式であるし，奥津ら ${ }^{2)}$ は非骨化性線維腫，骨 軟骨腫, 骨囊腫, 動脈瘤様骨豪腫, アミロイド骨囊腫, 骨巨細胞腫, 線維性骨異形成にも実施可能な術式であ ると述べている.

本術式の長所としては，(1)小皮切，(2)骨ペース卜充 填による早期の骨強度獲得, (3)早期の可動域訓練可能, (4)拡大画像による正確な病巣掻爬が挙げられる.

一方短所としては, (1)適応部位の制限, (2)腫瘍播種, (3)骨ペースト皮下漏出が挙げられる。(1)適応拡大につ いては今後症例を蓄積しながら十分な検討が必要であ るが，(2)は術前の十分な画像評価および術中迅速病理 の併用により対応可能と思われ, (3)については現在の ところ自験例や文献的にも重篤な問題となった例は無 いようである。今回我々が経験した手指骨の内軟骨腫
は，内視鏡下手術の最も良い適応と思われるが，今後 他の部位や他の良性骨腫瘍に対しても応用可能かどう か症例を十分に積み重㱛て検討していきたいと考えて いる.

ま と め

手指内軟骨腫 4 手に対する内視鏡視下掻爬術の短期 成績は良好であった。本法は種々の長所をあち有用な 術式であると思われた。

\section{参 考 文 献}

1）小林正明ほか：手指の良性骨腫瘍に対する鏡視手術. 整形外科最小侵襲手術ジャーナル, $28: 2-8,2003$.

2）奥津一郎ほか：良性骨腫瘍に対する鏡視手術. 整形外 科最小侵襲手術ジャーナル，28：15-20，2003.

3）関谷勇人ほか：関節外鏡視手術一骨腫瘍一。整形外科 最小侵襲手術ジャーナル，16：61-68，2000.

4）湯川昌広ほか：手指内軟骨腫鏡視下掻爬・人工骨ペー ス卜注入治療の経験. 日本手の外科学会雑誌, 22(1) : S45, 2005 . 